\title{
A MAGYAR PSZICHOLÓGIAI SZEMLE FŐSZERKESZTŐJÉNEK KÖSZÖNTŐJE
}

Oláh Attila, az Eötvös Loránd Tudományegyetem Pedagógiai és Pszichológiai Karának egyetemi tanára nyolc éven át volt a Magyar Pszichológiai Társaság elnöke (2008-2016). A Magyar Pszichológiai Szemle a Magyar Pszichológiai Társaság lapja, ezért a 70. születésnap alkalmából a lap örömmel tiszteleg munkássága elôtt kollégáinak és tanítványainak tematikusan összegyújtött, a folyóirat szabályainak megfelelốen referált tudományos cikkeivel, amelyeket a szám vendégszerkesztôi, Urbán Róbert, Nagy Henriett és Magyaródi Tímea felügyeltek. A lap fôszerkesztôje a szerkesztôség nevében is boldog születésnapot kíván Oláh Attilának.

Fülöp Márta

\section{BEVEZETÉS ÉS KÖSZÖNTÉS OLÁH ATTILA 70. SZÜLETÉSNAPJÁRA}

Oláh Attila inspiratív személye és munkássága széles körben ismert a magyar pszichológusok körében. Az eddigi tudományos tevékenységében jól azonosítható pályaíve az egyéni különbségek mérésétôl (pl. Oláh, 2005a) és tesztadaptációjától és a fejlesztéstôl (pl. Oláh, 1984; Oláh, 2005b), a stressz és a megküzdésben szerepet játszó személyiségjellemzók integrált szemléletén (lásd Pszichológiai immunrendszer, pl. Oláh, 2000) keresztül a pozitív pszichológia hazai teoretikus és empirikus megalapozásáig (Oláh, 2005c; Oláh, 2012; Oláh és Nagy, 2014) terjed. Oláh Attila termékeny életútját eddig 55 tanulmány és 30 szerzóként vagy szerkesztőként jegyzett kötet és 27 könyvfejezet jellemzi. Ennél talán még fontosabb a tanítványok széles köre. Oláh Attila munkásságában megnyilvánuló integrációra törekvố szemléletét jól tükrözi célkitúzése, miszerint szeretné elérni, hogy „a pozitív pszichológia a jelenlegi szénakazal állapotából, egy olyan összeszedett állapotba kerüljön, amelyben megszületik egy, a pszichológiatudomány klasszikus irányzataival is ringbe szállni képes, gazdag empirikus eredmé- 
nyeket integráló pozitív pszichológiai teória” (Oláh, 2012, 10). A Magyar Pszichológiai Szemle 2012 márciusában megjelent, pozitív pszichológia témájú különszáma elméleti és empirikus tanulmányok mentén összegezte a magyar pozitív pszichológia elsố tizenkét évét. A Magyar Pszichológiai Szemle jelenlegi száma Oláh Attila 70. születésnapjának tiszteletére készült, és célja nem egy terület áttekintése, hanem Oláh Attila sokszínú hatásának bemutatása tanítványok és közvetlen kollégák munkáin keresztül. Bár a jelen kötetben megjelenô tanítványok köre messze nem teljes, de bizakodhatunk, hogy a 80. születésnapra készülô számban a tanítványok és a hatások egy másik, még szélesebb körét tudjuk bemutatni.

A szerkesztók: Urbán Róbert, Nagy Henriett, Magyaródi Tímea

\section{IRODALOM}

Oláh, A. (2019). Positivity is an up-to-date predictor of well-functioning instead of a eudaemon. Asian Journal of Social Psychology, 22(2), 143-145.

Oláh A. (2012) (szerk.). A pozitíu pszichológia világa. Budapest: Akadémiai Kiadó.

Oláh, A. (2005a). Anxiety, coping, and flow. Empirical studies in interactional perspective. Budapest: Trefort Press.

Oláh A. (2005b). Szemiq: Képes fél-projektív teszt a szociális és érzelmi intelligencia mérésére. Budapest: HI Press.

Oláh A. (2005c). Érzelmek, megküzdés és optimális élmény: belsố világunk megismerésének módszerei. Budapest, Trefort Kiadó.

Oláh, A (2000): Health protective and health promoting resources in personality: A framework for the measurement of the psychological immune system. Paper presented at the Positive Psychology Meeting, Quality of Life Research Center, Claremont Graduate University, April 2000.

Oláh A. (1984). A Californiai Psychological Inventory (CPI) rövidített változatának ismertetése. Budapest: OPI.

Oláh, A. \& Nagy, H. (Eds) (2014). Flow, emotional intelligence and psychological immunity. Empirical Studies in Positive Psychology Perspective. Budapest: ELTE Eötvös Kiadó. 